\title{
THE INTERNAL DISTRIBUTION OF HYDROGEN IONS WITH VARYING DEGREES OF METABOLIC ACIDOSIS ${ }^{1}$
}

\author{
By WILLIAM B. SCHWARTZ,2 KARL' J. ØRNING, 3 AND RICHARD PORTER * \\ (From the Medical Service, New England Center Hospital, and the Department of Medicine, \\ Tufts University School of Medicine, Boston, Mass.)
}

(Submitted for publication July 12, 1956; accepted November 16, 1956)

When a mineral acid is administered to animal or man, a substantial fraction is buffered in sites other than blood or interstitial fluid. Van Slyke and Cullen (1) first observed that total blood volume could account for the buffering of only onesixth of a mineral acid load and suggested that buffer substances throughout the body, including those of the tissues, are utilized in the defense against metabolic acidosis. Recent studies in several laboratories have provided more detailed quantitative data on the internal distribution of administered hydrogen ions. Swan and Pitts (2) in nephrectomized dogs and Schwartz, Jenson, and Relman (3) in normal human subjects have demonstrated that only about one-half of a mineral acid load is buffered in the extracellular space and red blood cells. The remaining hydrogen ions exchange with sodium and potassium from tissue and bone and are presumably buffered in these areas.

The purpose of this investigation was to determine whether the partition of administered hydrogen ions between the intra and extracellular phases is the same regardless of the magnitude of the acid load, or whether variation in the severity of the acidosis results in preferential utilization of one or the other of the buffer compartments. In the present experiments the distribution of hydrogen was determined in dogs made progressively acidotic by the intravenous administration

1 This study was supported in part by grants from the National Heart Institute of the National Institutes of Health, United States Public Health Service, the American Heart Association and the Massachusetts Heart Association.

2 This work was done during the tenure of an Established Investigatorship of the American Heart Association.

${ }^{3}$ Supported by a grant from the Royal Norwegian Ministry of Foreign Affairs and by a Fulbright Travel Grant.

4 This work was done during the tenure of a Research Fellowship of the American Heart Association. of hydrochloric acid. The data demonstrate that when equilibrium is allowed to occur the partition of hydrogen ions between extracellular and intracellular buffers is essentially unaffected by the degree of acidosis.

\section{MATERIALS AND METHODS}

Experiments were performed in 24 healthy mongrel dogs weighing from 10.5 to $21.8 \mathrm{Kg}$. Small doses of morphine were used for sedation during the preparatory manipulations. The femoral artery and vein were cannulated with polyvinyl catheters. An indwelling catheter was inserted in the bladder, and a Levine tube was introduced into the stomach and left in place for the duration of the experiment. Heparinized arterial blood was collected anerobically for determination of $\mathrm{pH}$, total carbon dioxide content, sodium, potassium, chloride, hematocrit, hemoglobin and total protein. Measurements were made of urinary titratable acid, ammonium, phosphorus, sodium, potassium, and chloride. The volume of gastric juice was measured periodically, and a 5-cc. aliquot was removed for determination of total acid content. The remainder of the gastric content was promptly returned to the stomach. The analytic procedures employed in this study have been described in a previous paper from this laboratory (4). Following a control period of 30 to 60 minutes, during which urine and several blood samples were collected, hydrochloric acid in isotonic glucose was administered intravenously by means of a Bowman infusion pump. Employing concentrations of 0.5 to $1.2 \mathrm{~N}$ hydrochloric acid, it was ordinarily possible to limit the amount of fluid given to less than 5 per cent of estimated total body water. At the completion of the experiments, most of the animals were sacrificed and the volume and total acidity of the stomach contents determined. The small intestine was also regularly examined, but the volume of fluid was small and no measurement of volume or composition was attempted.

Two types of experiments were performed. In the first group of 14 continuous infusion experiments hydrochloric acid was administered without interruption until the animal died or the plasma bicarbonate concentration fell to less than $5 \mathrm{mEq}$. per $\mathrm{L}$. In 11 experiments the rate of acid infusion was roughly 80 microequivalents per kilogram per minute and in three, 160 microequivalents per kilogram per minute. In the second group of ten intermittent infusion experiments hydrochloric acid was 
TABLE I

Effects of continuous infusion of hydrochloric acid

Dog No. 98. Weight $14.1 \mathrm{Kg}$.; $\mathrm{HCl} 0.750 \mathrm{~N}$ in $5 \%$ glucose infused at approximately 80 microequivalents $/ \mathrm{Kg} . / \mathrm{min}$.; Hemoglobin $17.2 \mathrm{Gm} . / 100$ cc.; Hematocrit 41.5\%; Plasma protein $5.8 \mathrm{Gm} . / 100 \mathrm{cc}$.

\begin{tabular}{|c|c|c|c|c|c|c|c|c|c|c|c|c|c|c|c|}
\hline \multicolumn{16}{|c|}{ A. Experimental observations } \\
\hline \multirow{2}{*}{$\begin{array}{c}\text { Total } \\
\text { elapsed } \\
\text { time }\end{array}$} & \multicolumn{6}{|c|}{ Plasma } & \multicolumn{7}{|c|}{ Urine } & \multicolumn{2}{|c|}{ Gastric juice } \\
\hline & $\mathrm{pH}$ & $\mathrm{pCO}_{2}$ & $\mathrm{HCO}_{2}$ & $\mathrm{Cl}$ & $\mathrm{Na}$ & $\mathbf{K}$ & Flow & $\mathrm{pH}$ & $\mathrm{NH}_{4}$ & TA & $\mathrm{Cl}$ & $\mathrm{Na}$ & $\mathbf{K}$ & Volum & Total H \\
\hline $\min$. & & $m m . H$ & Ig $m E q . / L$ & $m E q . / L$ & $m E q . / L$. & $m E q . / L$. & $c c . / m i n$. & & $\underset{\text { min. }}{\mu E q . /}$ & $\begin{array}{c}\mu E q . / \\
\min .\end{array}$ & $\underset{\min .}{\mu E q . /}$ & $\begin{array}{c}\mu E q . / \\
\text { min. }\end{array}$ & $\underset{\text { min. }}{\mu E q . /}$ & $c c$. & $m E q$. \\
\hline \multirow[t]{2}{*}{$\begin{array}{r}-39 \\
0\end{array}$} & $\begin{array}{l}7.37 \\
7.37\end{array}$ & $\begin{array}{l}43 \\
45\end{array}$ & $\begin{array}{l}24.2 \\
25.4\end{array}$ & $\begin{array}{l}111 \\
112\end{array}$ & $\begin{array}{l}146 \\
146\end{array}$ & $\begin{array}{l}3.5 \\
3.6\end{array}$ & 0.35 & 6.70 & 9 & 2 & 29 & 18 & 28 & 5 & 0 \\
\hline & \multicolumn{13}{|c|}{$\mathrm{HCl}$ infusion begun at $0 \mathrm{~min}$. at $1.35 \mathrm{cc} . / \mathrm{min}$. } & & \\
\hline $\begin{array}{r}15 \\
30 \\
60 \\
90 \\
120 \\
150 \\
165 \\
180 \\
201\end{array}$ & $\begin{array}{l}7.28 \\
7.26 \\
7.14 \\
7.06 \\
6.94 \\
6.81 \\
6.73 \\
6.68 \\
\text { Dog }\end{array}$ & $\begin{array}{r}46 \\
41 \\
38 \\
33 \\
30 \\
22 \\
20 \\
17 \\
\text { died. }\end{array}$ & $\begin{array}{r}20.7 \\
17.7 \\
12.4 \\
9.1 \\
6.3 \\
3.4 \\
2.5 \\
2.0 \\
\text { Gastric c }\end{array}$ & $\begin{array}{c}118 \\
124 \\
127 \\
130 \\
134 \\
134 \\
\text { content }\end{array}$ & $\begin{array}{l}144 \\
141 \\
141 \\
140 \\
138 \\
\\
133 \\
\text { autor }\end{array}$ & $\begin{array}{c}3.6 \\
3.9 \\
4.2 \\
5.2 \\
6.5 \\
\\
8.4 \\
\text { y: } 35\end{array}$ & $\begin{array}{c}0.35 \\
0.63 \\
0.37 \\
\text { cc., cont }\end{array}$ & $\begin{array}{r}5.34 \\
\text { hing } 0\end{array}$ & $\begin{array}{r}8 \\
22 \\
8 \\
35 \mathrm{mEc}\end{array}$ & $\begin{array}{c}18 \\
12 \\
\\
59 \\
\mathrm{H}^{+} .\end{array}$ & $\begin{array}{l}12 \\
65\end{array}$ & $\begin{array}{r}6 \\
26 \\
22\end{array}$ & $\begin{array}{l}18 \\
34\end{array}$ & $\begin{array}{l}13 \\
23\end{array}$ & $\begin{array}{l}0 \\
0.1 \\
0\end{array}$ \\
\hline
\end{tabular}

B. Derived data

\begin{tabular}{|c|c|c|c|c|c|c|c|c|c|c|c|}
\hline \multirow{2}{*}{$\begin{array}{c}\text { Total } \\
\text { elapsed } \\
\text { time }\end{array}$} & \multirow[b]{2}{*}{$\underset{\text { volume* }}{\text { ECF }}$} & \multirow[b]{2}{*}{$\begin{array}{c}\text { Hydrogen } \\
\text { infused }\end{array}$} & \multicolumn{7}{|c|}{ Distribution of administered hydrogen ions } & \multicolumn{2}{|c|}{ Shifts in IC electrolytes } \\
\hline & & & Urinet & Gastric & $\underset{\text { HCO }}{\text { ECF }}$ & $\begin{array}{l}\text { Plasma } \\
\text { protein }\end{array}$ & $\underset{\mathrm{HBC}}{\mathrm{RBC}}$ & $\mathbf{H g b}$ & ICF & $\Delta \mathrm{Na}$ & $\Delta \mathrm{K}$ \\
\hline $\min$. & $\boldsymbol{L}$. & $m E q$. & $m E q$. & $m E q$. & $m E q$. & $m E q$. & $m E q$. & $m E q$. & $m E q$. & $m E q$ & $m E q$. \\
\hline $\begin{array}{r}30 \\
60 \\
90 \\
120 \\
150 \\
180\end{array}$ & $\begin{array}{l}2.91 \\
2.99 \\
3.12 \\
3.25 \\
3.35 \\
3.56\end{array}$ & $\begin{array}{l}30.3 \\
30.3 \\
30.3 \\
30.3 \\
30.3 \\
30.3\end{array}$ & $\begin{array}{l}0 \\
0 \\
1 \\
1 \\
0 \\
0\end{array}$ & $\begin{array}{l}0 \\
0 \\
0 \\
0 \\
0 \\
0\end{array}$ & $\begin{array}{r}20 \\
16 \\
10 \\
9 \\
10 \\
5\end{array}$ & $\begin{array}{l}0.4 \\
0.4 \\
0.3 \\
0.4 \\
0.5 \\
0.5\end{array}$ & $\begin{array}{l}1.6 \\
1.1 \\
0.6 \\
0.6 \\
0.6 \\
0.3\end{array}$ & $\begin{array}{l}2.7 \\
3.2 \\
2.1 \\
3.3 \\
3.8 \\
4.1\end{array}$ & $\begin{array}{r}5 \\
9 \\
16 \\
16 \\
15 \\
20\end{array}$ & $\begin{array}{r}-7 \\
-3 \\
-19 \\
-15 \\
-9 \\
-11\end{array}$ & $\begin{array}{r}0 \\
-1 \\
-1 \\
-4 \\
-5 \\
-8\end{array}$ \\
\hline
\end{tabular}

* Initial ECF volume estimated as 20 per cent BW (2.82 L.). interval.

† Urine was collected less frequently than blood, and urine acid losses were assumed to be constant over the collection

administered in an interrupted manner, each experiment consisting of a series of 45-minute infusions during which acid was given at the rate of approximately 80 microequivalents per kilogram per minute. A two-hour equilibration period was allowed after each of the infusion periods. ${ }^{5}$ Blood specimens were obtained at the beginning and end of each acid infusion, and serially 60,105 , and 120 minutes after acid had been discontinued. In all experiments reported the cumulative loss of gastric juice was less than $100 \mathrm{cc}$. (10 mEq. or less of $\left.\mathrm{H}^{+}\right)$and urine increment in acid excretion (ammonium plus titratable acid) less than 10 per cent of the administered load. Several additional intermittent infusion experiments were excluded from the study because gastric or urinary losses considerably exceeded these limits.

5 This interval was used because in preliminary studies it was found that the rise in plasma bicarbonate concentration, which began immediately after each infusion was stopped, was essentially complete in two hours.

\section{Calculations}

Hydrogen ion balance was calculated in a manner previously described (3). Retained acid was taken as the difference between hydrochloric acid administered and the increment in gastric acid secretion and urine acid excretion (ammonium plus titratable acid). The distribution of hydrogen ion in the buffers of the blood was estimated in the fashion described by Singer and Hastings (5). For these calculations blood volume was taken to be $70 \mathrm{cc}$. per kilogram of body weight, and red cell and plasma volume were considered to be constant, ignoring the small error introduced by withdrawal of blood. Initial extracellular fluid volume was taken to be 20 per cent of body weight and subsequent alterations estimated from changes in the "chloride space." The buffer contribution of extracellular bicarbonate was calculated from the observed reduction in plasma concentration with the use of a combined Donnan and plasma water correction factor of 1.11. Intracellular buffering was taken as the difference between total retained hydrogen ions and that 
buffered by the extracellular space. ${ }^{b}$ Internal exchanges of sodium and potassium were estimated in the usual fashion from "chloride space" calculations. Shifts of potassium were interpreted on the assumption that there were no significant changes in nitrogen balance in the course of the experiment. Hemolysis was seen frequently at bicarbonate levels of less than $6 \mathrm{mEq}$. per $\mathrm{L}$., but its effect upon calculated potassium shifts was ignored since the potassium content of dog erythrocytes is only from 4 to $12 \mathrm{mEq}$. per L. (7).

\section{RESULTS}

\section{Part I. Continuous infusion experiments}

Distribution of hydrogen ions among the body buffers. Table IA summarizes the data from one of 14 experiments in which acid was infused continuously. The upper half of Figure 1 shows the plasma bicarbonate concentration plotted as a function of time in minutes. The rate of decrease in bicarbonate concentration was initially rapid but slowed progressively during the experiment. Thus, in the first half-hour a reduction of $8 \mathrm{mEq}$. per L. occurred but in the last half-hour of the study an equal quantity of infused acid reduced bicarbonate concentration by only $1.4 \mathrm{mEq}$. per L. Twelve of the 14 experiments demonstrated a similar pattern of change in plasma bicarbonate concentration.

Table IB gives the calculated values for distribution of acid based upon measurements made at regular intervals during the course of the acid infusion. Acid distribution between intracellular and extracellular fluid for each period of infusion is shown non-cumulatively in the lower half of Figure 1 and in Table IB, and demonstrates an apparent small intracellular buffer contribution early in the study with a much larger intracellular buffer contribution during the latter part of the experiment. Thus, extracellular buffers accounted for 83 per cent and intracellular buffers 17 per cent of the first $2.1 \mathrm{mEq}$. per kilogram of acid administered. In contrast, during the final pe-

\footnotetext{
${ }^{6}$ Red blood cell buffers make a relatively small and constant contribution to total buffering and have been included with the buffers of the extracellular fluid. The term "intracellular" is used broadly in this discussion to refer to all non-extracellular areas in which hydrogen buffering might occur. This probably includes not only muscle and other soft tissues, but also bone, which has been demonstrated to have a large labile store of sodium and potassium (6).
}
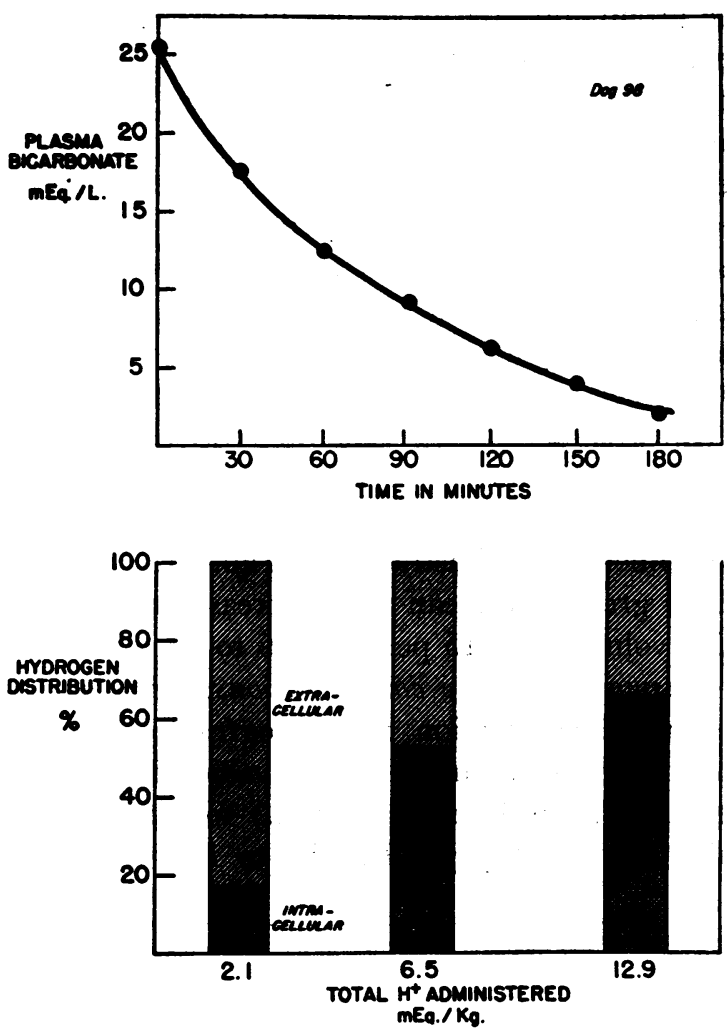

Fig. 1. The Effects of Continuous Infusion of HYDROCHLORIC ACID

Plasma bicarbonate concentration is shown in the upper portion. Calculated hydrogen distribution is shown non-cumulatively in the lower portion. Note the exponential fall in plasma bicarbonate concentration and the apparent progressive increase in intracellular buffering as acidosis becomes more severe.

riod of the experiment the extracellular space buffered only 34 per cent of the last $2.1 \mathrm{mEq}$. per kilogram of acid administered, the intracellular phase now having buffered 66 per cent.

In the group of 14 continuous acid infusion experiments, the total acid administered varied from 6.8 to $15.8 \mathrm{mEq}$. per $\mathrm{Kg}$., a quantity sufficient to reduce plasma bicarbonate concentration in each case to less than $5 \mathrm{mEq}$. per L. Figure 2 summarizes the calculations of intracellular buffering for the entire group of continuous infusion experiments. Intracellular buffering for the $14 \mathrm{ex}-$ periments is plotted against total administered acid but in a non-cumulative fashion. Each point, therefore, represents only that buffering calculated to have occurred in the immediately preceding period of infusion. The overall pattern for 
the group appeared to be one of increasing intracellular buffer contribution during the first half of the experiment with a gradual levelling off as the intracellular contribution approached 40 to 60 per cent of the load. The mean intracellular buffer contribution was 16 per cent of the first increment of acid as compared to a mean intracellular uptake of 55 per cent of the last equal increment. In one entirely atypical experiment there appeared to be a steady decrement in intracellular buffering.

Extracellular fluid volume. Extracellular fluid volume, as estimated from changes in "chloride space," increased steadily during infusion in all experiments, as illustrated in Table I. For the entire group the mean total increase in extracellular volume was 15 per cent ( 6 to 26 per cent).

Plasma electrolyte concentrations. Plasma potassium concentration rose progressively in all animals from the mean control value of $3.2 \mathrm{mEq}$. per L. (2.5 to $3.6 \mathrm{mEq}$. per L.) to a final mean value of $6.6 \mathrm{mEq}$. per L. (5.0 to $10.9 \mathrm{mEq}$. per

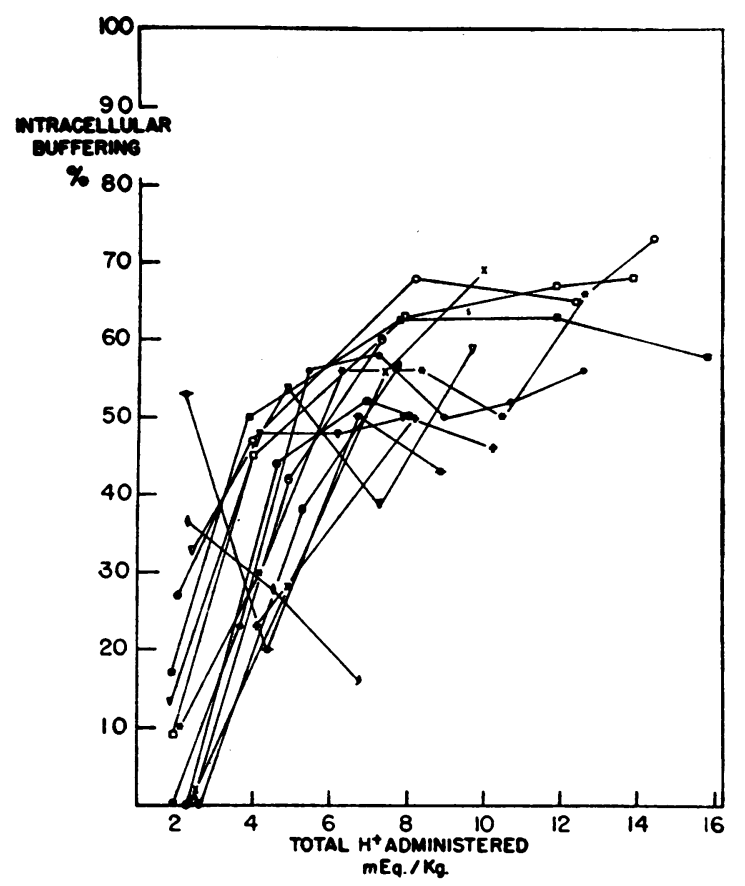

Fig. 2. Apparent Intracellular Buffer Contribution During Continuous Infusion OF HydroCHLORIC ACID

Intracellular buffering for the 14 experiments is plotted against total administered acid but in a non-cumulative fashion. Each point, therefore, represents only that buffering calculated to have occurred in the immediately preceding period of infusion. Note the apparent rise in intracellular buffering as acidosis becomes more severe.
L.). The mean increase in concentration was 3.4 mEq. per L. ( 0.6 to $7.9 \mathrm{mEq}$. per L.).

Plasma sodium concentration decreased slightly but significantly during infusion from the mean control value of $144 \mathrm{mEq}$. per L. (139 to 151 $\mathrm{mEq}$. per L.) to a final mean value of $138 \mathrm{mEq}$. per L. (133 to $145 \mathrm{mEq}$. per L.).

Exchanges of electrolytes. The estimated total shift of potassium from intracellular fluid for the group of experiments had a mean value of 1.33 $( \pm 0.91) \mathrm{mEq}$. per $\mathrm{Kg}$. The estimated total shift of sodium from intracellular fluid for the group as a whole had a mean value of 3.26 $( \pm 1.67) \mathrm{mEq}$. per $\mathrm{Kg}$. and comprised roughly two-thirds of the estimated intracellular cation loss.
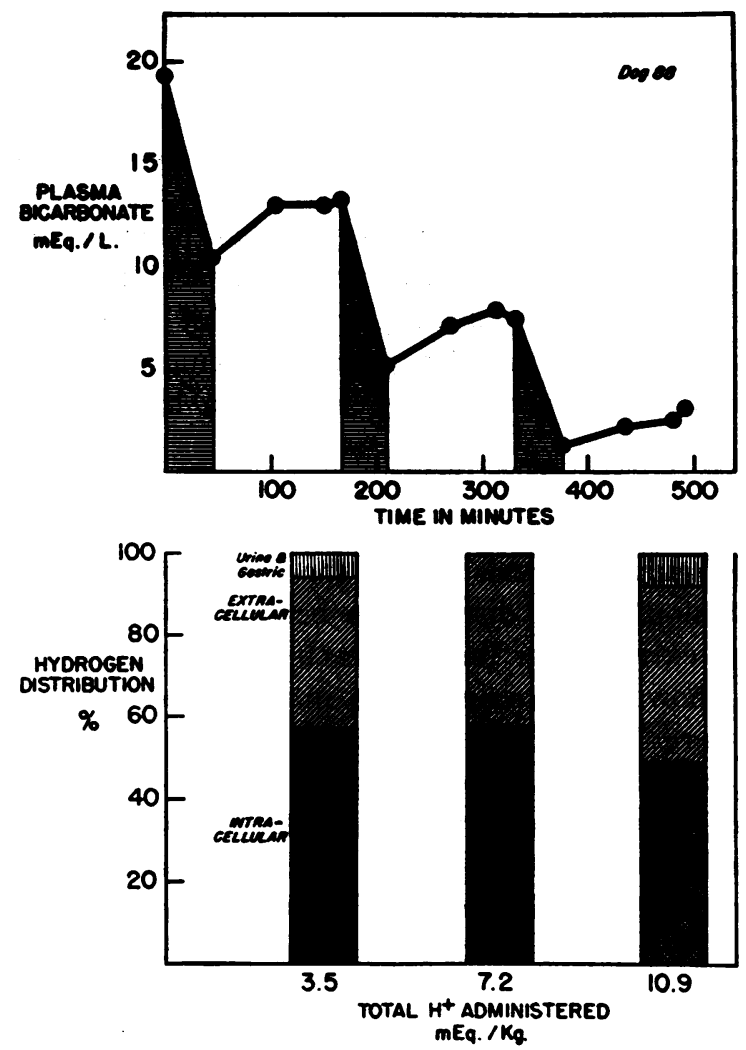

Fig. 3. The Effects of Intermittent Infusion of HYDROCHLORIC ACID

Plasma bicarbonate concentration is shown in the upper portion where the periods of infusion are indicated by the shaded areas. Calculated hydrogen ion distribution is shown non-cumulatively in the lower portion. Note the rebound in plasma bicarbonate concentration during the equilibration period following each infusion, and the roughly constant contributions of extracellular and intracellular buffers at all degrees of acidosis. 
TABLE II

Effects of intermittent infusion of hydrochloric acid

Dog No. 88. Weight $21.8 \mathrm{Kg}$; $\mathrm{HCl} 1.16 \mathrm{~N}$ in $5 \%$ glucose infused at approximately 80 microequivalents $/ \mathrm{Kg}$./min.; Hemoglobin $16.4 \mathrm{Gm} .1100$ cc.; Hematocrit $52 \%$; Plasma protein $6.2 \mathrm{Gm} . / 100 \mathrm{cc}$.

\begin{tabular}{|c|c|c|c|c|c|c|c|c|c|c|c|c|c|c|c|}
\hline \multicolumn{16}{|c|}{ A. Experimental observations } \\
\hline \multirow{2}{*}{$\begin{array}{c}\text { Total } \\
\text { elapsed } \\
\text { time }\end{array}$} & \multicolumn{6}{|c|}{ Plasma } & \multicolumn{7}{|c|}{ Urine } & \multicolumn{2}{|c|}{ Gastric juice } \\
\hline & $\mathrm{pH}$ & $\mathrm{pCO}_{2}$ & $\mathrm{HCO}_{2}$ & Cl & $\mathrm{Na}$ & $\mathbf{K}$ & Flow & $\mathrm{pH}$ & $\mathrm{NH}_{4}$ & TA & $\mathbf{C l}$ & $\mathrm{Na}$ & $\mathbf{K}$ & Volume & Total H \\
\hline min. & & $m m . H_{\varepsilon}$ & $m E_{Q} / L$. & $m E q . / L$ & $w B_{q} / L$ & $n E q . / L$. & cc./min. & & ${ }_{\substack{\mu R_{q} / \\
\text { mim. }}}$ & ${ }_{\text {ming. }}$ & $\underset{\text { mine. }}{\mu E_{q} /}$ & $\begin{array}{c}m E_{q . l} \\
\text { mix. }\end{array}$ & $\begin{array}{c}\mu E q . / \\
\text { min. }\end{array}$ & $c c$. & $m E q$ \\
\hline \multirow[t]{2}{*}{$\begin{array}{r}-101 \\
0\end{array}$} & $\begin{array}{l}7.39 \\
7.36\end{array}$ & $\begin{array}{l}33 \\
35\end{array}$ & $\begin{array}{l}19.1 \\
19.0\end{array}$ & $\begin{array}{l}112 \\
112\end{array}$ & $\begin{array}{l}147 \\
147\end{array}$ & $\begin{array}{l}3.0 \\
3.1\end{array}$ & 0.21 & 6.2 & 11 & 5 & 40 & 45 & 11 & $\mathbf{0}$ & $\mathbf{0}$ \\
\hline & \multicolumn{15}{|c|}{$\mathrm{HCl}$ infused from $0-45 \mathrm{~min}$. at $1.46 \mathrm{cc} . / \mathrm{min}$. } \\
\hline \multirow[t]{2}{*}{$\begin{array}{r}45 \\
105 \\
150 \\
165\end{array}$} & $\begin{array}{l}7.23 \\
7.32 \\
7.37 \\
7.35\end{array}$ & $\begin{array}{l}26 \\
26 \\
23 \\
24\end{array}$ & $\begin{array}{l}10.5 \\
13.0 \\
13.0 \\
13.1\end{array}$ & $\begin{array}{r}122 \\
120\end{array}$ & $\begin{array}{l}144 \\
145\end{array}$ & 3.6 & 0.50 & 6.0 & 19 & 15 & 59 & 36 & 53 & 25 & 1.4 \\
\hline & \multicolumn{15}{|c|}{$\mathrm{HCl}$ infused from $165-210 \mathrm{~min}$. at $1.49 \mathrm{cc} . / \mathrm{min}$. } \\
\hline \multirow[t]{2}{*}{$\begin{array}{l}210 \\
270 \\
315 \\
330\end{array}$} & $\begin{array}{l}7.10 \\
7.20 \\
7.25 \\
7.26\end{array}$ & $\begin{array}{l}17 \\
19 \\
18 \\
17\end{array}$ & $\begin{array}{l}5.2 \\
7.2 \\
7.7 \\
7.4\end{array}$ & $\begin{array}{l}132 \\
126\end{array}$ & $\begin{array}{l}143 \\
142\end{array}$ & 4.6 & 0.16 & & 2 & 1 & 8 & 2 & 7 & 5 & $t$ \\
\hline & \multicolumn{15}{|c|}{$\mathrm{HCl}$ infused from $330-375 \mathrm{~min}$. at $1.44 \mathrm{cc} . / \mathrm{min}$. } \\
\hline \multirow[t]{2}{*}{$\begin{array}{l}375 \\
435 \\
480 \\
495\end{array}$} & $\begin{array}{l}6.87 \\
7.07 \\
7.06 \\
7.09\end{array}$ & $\begin{array}{r}7 \\
8 \\
9 \\
10\end{array}$ & $\begin{array}{l}1.2 \\
2.2 \\
2.4 \\
3.0\end{array}$ & $\begin{array}{l}138 \\
132\end{array}$ & $\begin{array}{l}140 \\
139\end{array}$ & 7.2 & 0 & & & & & & & 85 & 7.0 \\
\hline & \multicolumn{15}{|c|}{ Animal sacrificed. Gastric content at autopsy: $85 \mathrm{cc}$ containing $7.0 \mathrm{mEq} . \mathrm{H}^{+}$} \\
\hline
\end{tabular}

B. Derived data

\begin{tabular}{|c|c|c|c|c|c|c|c|c|c|c|c|}
\hline \multirow[b]{2}{*}{$\begin{array}{c}\text { Infusion } \\
\text { period }\end{array}$} & \multirow[b]{2}{*}{$\underset{\text { volume* }}{\text { ECF }}$} & \multirow[b]{2}{*}{$\begin{array}{c}\text { Hydrogen } \\
\text { infused }\end{array}$} & \multicolumn{7}{|c|}{ Distribution of administered hydrogen ions } & \multicolumn{2}{|c|}{ Shifts in IC electrolytes } \\
\hline & & & Urine & Gastric & $\begin{array}{c}\mathrm{ECF} \\
\mathrm{HCO},\end{array}$ & $\begin{array}{l}\text { Plasma } \\
\text { protein }\end{array}$ & $\begin{array}{l}\mathrm{RBC} \\
\mathrm{HCO},\end{array}$ & Hgb & ICF & $\Delta \mathbf{N a}$ & $\Delta \mathbf{K}$ \\
\hline & L. & $m E q$. & $m E q$. & $m E q$. & $m E q$. & $m E q$. & $m E q$. & $m E q$. & $m E q$. & $m E q$. & $m E q$. \\
\hline III & $\begin{array}{l}4.62 \\
4.95 \\
5.22\end{array}$ & $\begin{array}{l}77 \\
78 \\
76\end{array}$ & $\begin{array}{l}3 \\
0 \\
0\end{array}$ & $\begin{array}{l}1.4 \\
0 \\
5.6\end{array}$ & $\begin{array}{l}25 \\
27 \\
23\end{array}$ & $\begin{array}{l}0.1 \\
0.4 \\
0.8\end{array}$ & $\begin{array}{l}2.4 \\
2.2 \\
1.8\end{array}$ & $\begin{array}{l}1.2 \\
3.2 \\
6.8\end{array}$ & $\begin{array}{l}44 \\
45 \\
38\end{array}$ & $\begin{array}{l}-29 \\
-34 \\
-22\end{array}$ & $\begin{array}{l}-12 \\
-13 \\
-13\end{array}$ \\
\hline
\end{tabular}

* Initial ECF volume estimated as 20 per cent BW (4.36 L.).

† Assumed to have been same as period I.

$p H$ and $p \mathrm{CO}_{2}$. The mean control $\mathrm{pH}$ was 7.35 (7.28 to 7.45). $\mathrm{pH}$ regularly fell during acid administration in a roughly linear fashion. The mean final $\mathrm{pH}$ was 6.74 (6.45 to 7.05). $\mathrm{pCO}_{2}$ regularly fell in a roughly linear fashion during acid administration from a mean initial value of $42.4 \mathrm{~mm}$. $\mathrm{Hg}$ (32 to $49 \mathrm{~mm}$. $\mathrm{Hg}$ ) to a final mean value of $17 \mathrm{~mm}$. $\mathrm{Hg}$ ( 9 to $24 \mathrm{~mm}$. $\mathrm{Hg}$ ).

\section{Part II. Intermittent infusion experiments}

Distribution of hydrogen ions among the body buffers. Table IIA and Figure 3 summarize data from one of ten experiments in which a two-hour equilibration period was permitted after each of a series of 45-minute acid infusions. In the upper half of Figure 3 the periods of acid infusion are represented by the shaded areas. Plasma bicarbonate concentration fell sharply during each period of acid administration, rose sharply during the first hour of equilibration, and gradually levelled off by the end of two hours. In this experiment bicarbonate concentration rose during equilibration by an amount equal to approximately 30 per cent of the initial fall. The bicarbonate decrements resulting from the first two acid infusions were of the same order of magnitude, but in the last period it was slightly less. In each experiment the pattern of change in plasma bicarbonate concentration was essentially the same, 


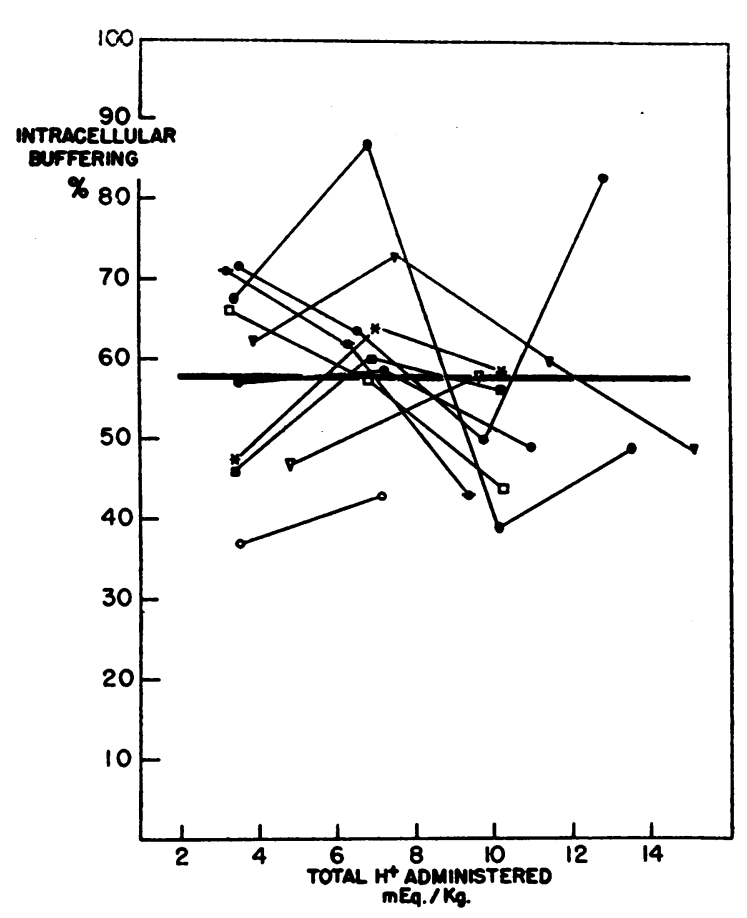

Fig. 4. Intracellular Buffering of Successive ACID INCREMENTS DURING INTERMITTENT HydRochloric ACID INFUSION EXPERIMENTS

Intracellular buffering for the ten experiments is plotted against total administered acid but in a non-cumulative fashion. Each point, therefore, represents only that buffering calculated to have occurred at equilibrium following the immediately preceding period of infusion. Note the absence of any consistent trend in intracellular buffering as acidosis becomes more severe, and the random variations about the mean value. Mean of average slopes $=-0.507( \pm 2.37)$, not significantly different from zero $(t=0.642, p>0.40)$. Mean intracellular buffering $=57.6$ per cent (standard deviation \pm 11.6 , standard error \pm 2.08 ).

showing a sharp fall during acid infusion and a rapid rise during the first hour of equilibration. During the second hour there was usually only a small additional rise. For the group as a whole, taking the mean of all the periods, the reduction in bicarbonate concentration during each infusion was $8.0 \mathrm{mEq}$. per L. During equilibration the rise in bicarbonate concentration in most instances tended to be slightly smaller in the second and third periods than in the first period of acid administration. The mean values for the net decrement in bicarbonate concentration after equilibration for successive periods were $6.3,4.6$, and $4.6 \mathrm{mEq}$. per L., respectively.
Table IIB gives the calculated values for distribution of acid based upon measurements made two hours after each infusion. Acid distribution between intracellular and extracellular fluid for each infusion period is shown non-cumulatively in the lower half of Figure 3. Intracellular buffering varied between 50 and 58 per cent, and extracellular buffering between 37 and 43 per cent during the course of the experiment. The remaining fraction of administered hydrogen ions appeared in urine and gastric juice.

In the entire group of intermittent infusion experiments, the total acid administered varied from 7.1 to $15.1 \mathrm{mEq}$. per $\mathrm{Kg}$. Some animals tolerated only two periods of infusion before developing lethal acidosis, others three and four. As will be seen, the amount of acid administered did not affect its pattern of distribution. Figure 4 summarizes the calculations of intracellular buffering for the entire group of intermittent experiments. Intracellular buffering for the ten experiments is plotted against total acid administered but in a non-cumulative fashion. Each point, therefore, represents only that buffering calculated to have occurred in the immediately preceding period of infusion. The slope for the best-fitting straight line was calculated for each of the ten experiments. The mean of the slopes of these lines was -0.507 $( \pm 2.37)$, a value not significantly different from zero $(t=0.642, p>0.40)$. The mean percentage buffering by intracellular fluid was 57.6 per cent (standard deviation \pm 11.6 , standard error \pm 2.08$)$.

The utilization of extracellular bicarbonate in the group as a whole did not appear to differ significantly with successive periods of infusion. For each experiment the average slope was calculated for a line defining extracellular bicarbonate utilization as a function of total administered acid. The mean of the ten average slopes was -0.411 $( \pm 1.15)$, a value not significantly different from zero $(t=1.07, p>0.30)$. The mean buffer contribution of red cells and plasma protein for the 31 infusion periods was $7.1 \pm 3.7$ per cent of the administered load.

Extracellular fuid volume. Extracellular fluid volume, as estimated from changes in "chloride space," increased steadily from period to period in all experiments, as illustrated in Table II. For the entire group the mean total increase in ex- 
tracellular volume was 17 per cent (10 to 28 per cent).

Plasma electrolyte concentrations. Plasma potassium concentration rose progressively in all animals from the mean control value of $2.9 \mathrm{mEq}$. per L. (2.4 to $3.1 \mathrm{mEq}$. per L.) to a final mean value of $6.7 \mathrm{mEq}$. per L. ( 5.5 to $8.5 \mathrm{mEq}$. per L.). The mean increase in concentration was $3.8 \mathrm{mEq}$. per L. (2.9 to $5.4 \mathrm{mEq}$. per L.).

Plasma sodium concentration decreased slightly but significantly during infusion from the mean control values of $144 \mathrm{mEq}$. per L. (139 to 150 $\mathrm{mEq}$. per L.) to a final mean value of $137 \mathrm{mEq}$. per L. (131 to $142 \mathrm{mEq}$. per L.).

Exchanges of electrolytes. The estimated shift of potassium from the intracellular space had a mean value of $2.58( \pm 1.16) \mathrm{mEq}$. per $\mathrm{Kg}$. Except for a consistently smaller shift with the first infusion, intracellular potassium loss was roughly constant for additional equal increments of acid. This is well illustrated by data shown in Table II.

Renal excretion of potassium increased in all but the three experiments in which oliguria developed. In the seven experiments where urine volume remained at the control level or increased, the total potassium loss estimated from the increment above control excretion averaged 2.3 $\mathrm{mEq}$. per $\mathrm{Kg}$. This urinary loss represented 68 per cent of the potassium calculated to have been displaced from cells.

The mean intracellular sodium loss for the group as a whole was $3.81( \pm 1.61) \mathrm{mEq}$. per $\mathrm{Kg}$., and comprised roughly 60 per cent of the estimated intracellular cation loss.

For the group as a whole the intracellular cation loss was of the same order of magnitude in each successive infusion period. For each experiment the average slope was calculated for a line defining intracellular cation loss as a function of total administered acid. The mean of the average slopes was $1.34( \pm 2.70)$, a value not significantly different from zero $(t=1.40, p>0.19)$. The mean value for hydrogen calculated to have entered cells in this group of experiments was 6.33 $( \pm 1.86) \mathrm{mEq}$. per $\mathrm{Kg}$., and the mean intracellular cation loss was $6.39( \pm 2.56) \mathrm{mEq}$. per $\mathrm{Kg}$. There is no significant difference between these values $(t=0.05, p>0.90)$.

$p H$ and $p \mathrm{CO}_{2}$. The mean control $\mathrm{pH}$ was 7.33 (7.26 to 7.38). For the group as a whole there was a roughly linear fall in $\mathrm{pH}$ with successive infusion periods to a final mean value of 7.03 (6.81 to 7.15). At equilibrium after six of 31 infusion periods, $\mathrm{pH}$ returned to within 0.02 units of the pre-infusion value.

The mean control $\mathrm{pCO}_{2}$ was $39 \mathrm{~mm}$. $\mathrm{Hg}$ (34 to $45 \mathrm{~mm} . \mathrm{Hg}$ ). For the group as a whole there was a roughly linear fall in $\mathrm{pCO}_{2}$ with successive infusion periods to a final mean value of $20 \mathrm{~mm}$. $\mathrm{Hg}$ ( 9 to $31 \mathrm{~mm}$. $\mathrm{Hg}$ ). In seven of 31 infusion periods, however, there was no significant change in $\mathrm{pCO}_{2}( \pm 3 \mathrm{~mm}$. $\mathrm{Hg})$.

\section{DISCUSSION}

The present studies indicate that the distribution of hydrogen ions among the body buffers is not affected by the magnitude of the acid load. The apparent predominance of extracellular buffering early in the course of continuous acid infusion does not represent the "steady state" response to metabolic acidosis. The fact that bicarbonate concentration rises sharply when the acid infusion is stopped reveals that the curvilinear fall in bicarbonate concentration during continuous acid infusion is the resultant of two opposing processes. On the one hand, the infusion of acid converts bicarbonate to carbonic acid thus tending to lower plasma bicarbonate concentration. On the other hand, the diffusion of bicarbonate from the interstitial fluid to plasma and the transfer of hydrogen ions from interstitial fluid to the intracellular space both tend to elevate plasma bicarbonate concentration. In the continuous infusion experiments this process did not have a chance to approach equilibrium until the late stages of the experiments when the bulk of administered acid had been given adequate time for distribution. In the intermittent infusion experiments, where equilibrium was allowed to occur at successive points during the study, the partition of hydrogen ions between extracellular and intracellular buffers was found to be essentially unaffected by the degree of acidosis.

Within individual experiments of the intermittent group there were often rather wide variations from period to period in the estimated contributions of the two buffer compartments, the standard deviation from the mean in Figure 4 being \pm 11.6 per cent. It seems probable that the most 


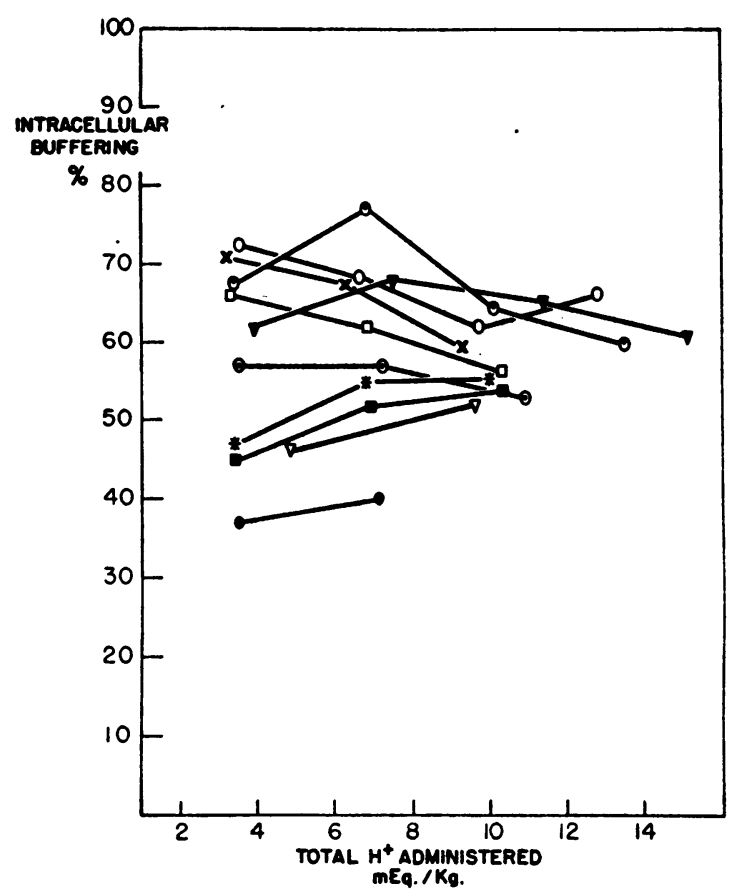

Fig. 5. Intracellular Buffering of Total AdminISTERed ACID DURINg Intermittent Hydrochloric ACI INFUSION EXPERIMENTS

Each point represents the total intracellular buffer contribution up to the time of any given equilibrium observation. Note that the variation in buffering of the total load by the intracellular area is less than 10 per cent in the course of nine of the ten experiments.

important factor in the production of these variations was the secretion and absorption of gastrointestinal juices. The single most critical measurement upon which the calculation of hydrogen distribution depends is plasma bicarbonate concentration. Sudden transfer of acid between plasma and the gastrointestinal tract by either secretion or reabsorption of gastric juice would markedly influence plasma bicarbonate concentration until equilibrium between plasma, interstitial fluid and tissues had been achieved. If such exchanges occurred shortly before collection of the "equilibrium" blood, significant distortion of the calculations of buffer distribution would result. Although total gastric losses were modest in the present series of experiments, changes in gastric acid content from period to period were probably large enough to have introduced significant artifacts and were probably the chief cause of the random variations in calculated buffer distribu- tion shown in Figure 4. On the other hand, urinary acid losses were constant enough presumably to have been of lesser significance.

Errors in calculation of extracellular fluid volume are probably of minor consequence in the interpretation of these experiments. As estimated from "chloride space," extracellular volume increased steadily in the course of every experiment. The mean increase in extracellular fluid agreed closely with the change in inulin and radiosulfate space found by Swan and Pitts following a single acid infusion in nephrectomized dogs (2). Although an assumed figure of 20 per cent of body weight was used for initial extracellular volume, substitution of other values between 15 per cent and 30 per cent does not significantly alter the calculated pattern of acid distribution.

The sources of error considered above are probably of the same absolute magnitude regardless of the quantity of acid administered. For this reason their relative importance in affecting the estimate of total hydrogen distribution based on a single measurement of plasma composition will be progressively less as acidosis increases. Thus when we consider the distribution of the total acid load administered up to any given time of observation (Figure 5) rather than the distribution of only the small increments of acid added within each period, the variation within each experiment is much smaller than that shown in Figure 4. In nine of the ten experiments the variation in intracellular buffering was less than 10 per cent. In metabolic acidosis the plasma bicarbonate concentration is affected by the total load of acid buffered in the extracellular space up to the time of blood sampling. Figure 5 suggests that at equilibrium in any given subject the quantity of acid buffered extracellularly bears a reasonably close relationship to the acid buffered within the cells. It follows, therefore, that a single bicarbonate determination will give a satisfactory though approximate estimate of the per cent reduction in total body buffer reserves. The rather large differences in distribution of acid between experiments (Figure 5) does not affect this conclusion, but it does suggest the difficulty of estimating the quantity of acid responsible for producing a given reduction in plasma bicarbonate concentration. The differences in the relative distribution of acid from subject to subject may in part have been the result 
of variations in the size of buffer stores, depending for example on the relative amounts of fat and lean tissue in a given animal.

In the present study hyperkalemia was observed in every experiment despite, in most instances, a normal urine flow and a marked increase in potassium excretion. Previous workers have noted sizable potassium shifts to extracellular fluid when metabolic acidosis was induced in nephrectomized animals $(2,8)$. The present data suggest that in acute metabolic acidosis, even with intact kidneys, the rate at which potassium is displaced by hydrogen exceeds the kidney's excretory capacity for this ion. The degree of hyperkalemia was directly related to the severity of the acidosis, although the rise in plasma potassium concentration was generally smallest in the animals with the largest increments in potassium excretion. Potassium concentration rose by an average of 3 to $4 \mathrm{mEq}$. per liter, but it is probable that elevations of this degree would not be maintained in chronic acidosis where more complete renal compensation could occur. It should be noted, however, that serum potassium concentration tends to be maintained at slightly elevated levels relative to total body potassium stores as long as $\mathrm{pH}$ remains low (9).

The mechanism governing the distribution of hydrogen ions through total body buffer stores is not clear from the present experiments. It seems likely that hydrogen ion distributes itself across cell membranes according to its electrochemical gradient (10). Thus any change in intracellular-extracellular gradient of hydrogen would tend to produce a shift of this ion. The present data show a progressive reduction in extracellular $\mathrm{pH}$ as more acid was administered, and it seems probable that this increase in hydrogen ion concentration was the major factor in the transfer of hydrogen ions to the intracellular space. There were, however, exceptions to this pattern in individual experiments where despite a fall in plasma bicarbonate concentration and a sizable movement of hydrogen into cells, there was little or no change in extracellular $\mathrm{pH}$. Nevertheless, hydrogen transfer may still be explained in terms of a change in hydrogen gradient, since in these instances extracellular $\mathrm{pH}$ was preserved by virtue of a sharp reduction in $\mathrm{pCO}_{2}$. Since a fall in $\mathrm{pCO}_{2}$ would probably be accompanied by a rise in intracellular $\mathrm{pH}$, even in the presence of a constant extracellular $\mathrm{pH}$ the gradient would be altered in a way favoring the inward movement of hydrogen ions. Thus, although there is no entirely predictable pattern in the change of either $\mathrm{pH}$ or $\mathrm{pCO}_{2}$, their individual effects on hydrogen gradient may act together to produce roughly the same hydrogen distribution. Further studies with control of $\mathrm{pCO}_{2}$ may serve to clarify this problem.

\section{SUMMARY}

Hydrochloric acid was administered intravenously to dogs in order to define the internal distribution of administered hydrogen ions with varying degrees of metabolic acidosis. Experiments in which acid was infused continuously appeared to indicate preferential utilization of extracellular buffers in the initial phase with the contribution of intracellular buffers becoming more important as the acidosis increased in severity. However, when the acid load was administered intermittently, allowing time for equilibrium to occur, the partition of hydrogen ions between extracellular and intracellular buffers was found to be essentially unaffected by the degree of acidosis. The data indicate that at equilibrium the percentage reduction in plasma bicarbonate concentration provided an approximate index of the percentage reduction in total body buffer stores.

\section{ACKNOWLEDGMENT}

The authors wish to express their appreciation to Dr. Jane Worcester of the Harvard School of Public Health for advice and assistance in the statistical analysis of the data.

\section{REFERENCES}

1. Van Slyke, D. D., and Cullen, G. E., Studies of acidosis. I. The bicarbonate concentration of the blood plasma; Its significance, and its determination as a measure of acidosis. J. Biol. Chem., 1917, 30, 289.

2. Swan, R. C., and Pitts, R. F., Neutralization of infused acid by nephrectomized dogs. J. Clin. Invest., 1955, 34, 205.

3. Schwartz, W. B., Jenson, R. L., and Relman, A. S., The disposition of acid administered to sodiumdepleted subjects: The renal response and the role of the whole body buffers. J. Clin. Invest., 1954, 33, 587.

4. Relman, A. S., and Schwartz, W. B., The effect of DOCA on electrolyte balance in normal man and 
its relation to sodium chloride intake. Yale $\mathrm{J}$. Biol. \& Med., 1952, 24, 540.

5. Singer, R. B., and Hastings, A. B., An improved clinical method for the estimation of disturbances of the acid-base balance of human blood. Medicine, 1948, 27, 223.

6. Bergstrom, W. H., and Wallace, W. M., Bone as a sodium and potassium reservoir. J. Clin. Invest., 1954, 33, 867.

7. Albritton, E. C., Standard Values in Blood, (Table 92-Blood electrolytes). Philadelphia, W. B. Saunders Co., 1952, p. 117.
8. Keating, R. E., Weichselbaum, T. E., Alanis, M., Margraf, H. W., and Elman, R., The movement of potassium during experimental acidosis and alkalosis in the nephrectomized dog. Surg., Gynec. \& Obst., 1953, 96, 323.

9. Scribner, B. H., Fremont-Smith, K., and Burnell, J. M., The effect of acute respiratory acidosis on the internal equilibrium of potassium. J. Clin. Invest., 1955, 34, 1276.

10. Boyle, P. J., and Conway, E. J., Potassium accumulation in muscle and associated changes. J. Physiol., $1941,100,1$.

\section{ANNOUNCEMENT OF MEETING}

The 49th Annual Meeting of the American Society for Clinical Investigation will be held in Atlantic City, New Jersey, on Monday, May 6, 1957, with headquarters at the Chalfonte-Haddon Hall. The scientific session will begin at 9 A.M. at the Steel Pier Theater. 